Supporting Information For

\title{
Exclusive Recognition of Acetone in a Luminescent BioMOF through Multiple Hydrogen-Bonding Interactions
}

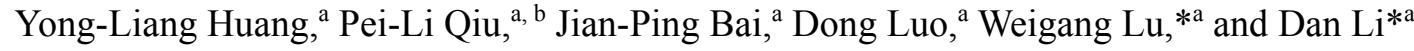 \\ ${ }^{a}$ College of Chemistry and Materials Science, Jinan University, Guangzhou 510632, P. R. China. \\ ${ }^{\mathrm{b}}$ Department of Chemistry, Shantou University, Guangdong 515063, P. R. China. \\ Email: weiganglu@jnu.edu.cn; danli@jnu.edu.cn
}

\section{Experimental Section}

\section{Materials and General Methods}

Commercially available chemicals were used without further purification. The ligand 1,3,6,8-tetrakis( $p$-benzoic acid)pyrene (short for $\mathrm{H}_{4} \mathrm{TBAPy}$ ) was synthesized according to the literature method. ${ }^{1}$ Infrared spectra (IR) were obtained in $\mathrm{KBr}$ disks using a Nicolet iS10 FTIR spectrometer in the range of 4000-400 $\mathrm{cm}^{-1}$. Solid state and solution luminescence spectra were measured on a Horiba FluoroLog-3 spectrofluorometer. Solid state UV-Vis spectra were recorded on Bio-Logic Mos-500. Elemental analyses of $\mathrm{C}, \mathrm{H}$, and $\mathrm{N}$ were carried out on an Elementar Vario Micro cube CHNS analyzer. Thermogravimetric analyses (TGA) were performed using a Mettler-Toledo (TGA/DSC1) thermal analyzer in the temperature range of $40-800{ }^{\circ} \mathrm{C}$ under nitrogen flow $\left(20 \mathrm{~mL} \cdot \mathrm{min}^{-1}\right)$ at a typical heating rate of $10{ }^{\circ} \mathrm{C} \mathrm{min}^{-1}$. Powder 
X-ray diffraction (PXRD) patterns of the bulk samples were measured on a Rigaku Ultima IV X-ray Diffractometer (40kV, $40 \mathrm{~mA}, \mathrm{Cu} \mathrm{K \alpha}, \lambda=1.5418 \AA$ ).

Synthesis of 1,3,6,8-tetrakis(4-(methoxycarbonyl)phenyl)pyrene A mixture of (4(methoxycarbonyl)phenyl)boronic acid $\quad(3.2463 \quad \mathrm{~g}, \quad 18.0 \quad \mathrm{mmol})$, 1,3,6,8-tetrabromopyrene $\quad(1.5540 \quad \mathrm{~g}, \quad 3.0 \quad \mathrm{mmol}), \quad$ palladium tetrakis(triphenylphosphine) $(0.1741 \mathrm{~g}, 0.15 \mathrm{mmol})$, and potassium carbonate $(3.3180$ $\mathrm{g}, 24 \mathrm{mmol}$ ) in dry dioxane was stirred under $\mathrm{N}_{2}$ for at $100{ }^{\circ} \mathrm{C} 72 \mathrm{~h}$. the reaction mixture was poured into water and extracted with dichloromethane. The extract was dried over magnesium sulfate, and the solvent volume was reduced under vacuum. The residue was passed through silica gel using a mixture of ethyl acetate and petroleum ether as eluent to give $81 \%$ yield $(1.7936 \mathrm{~g}, 2.43 \mathrm{mmol}) .{ }^{1} \mathrm{H}$ NMR $\left(\mathrm{CDCl}_{3}-\mathrm{d}\right): \delta 3.99(\mathrm{~s}, 12 \mathrm{H}), 7.75(\mathrm{~d}, 8 \mathrm{H}), 8.01(\mathrm{~s}, 2 \mathrm{H}), 8.15(\mathrm{~s}, 4 \mathrm{H}), 8.23(\mathrm{~d}, 8 \mathrm{H})$.

Synthesis of 1,3,6,8-tetrakis(p-benzoic acid)pyrene To a $250 \mathrm{~mL}$ round bottom flask add $\mathrm{THF} /$ dioxane/ $\mathrm{H}_{2} \mathrm{O}(5 / 2 / 2,180 \mathrm{~mL})$, 1,3,6,8-tetrakis(4-(methoxycarbonyl)phenyl)pyrene (1.4760 g, $2 \mathrm{mmol}), \mathrm{NaOH}(2.0 \mathrm{~g})$. The resultant suspension was vigorously stirred under reflux overnight. The solvents were removed under vacuum and water was added to the residue forming a clear yellow solution. The solution was stirred at room temperature for $2 \mathrm{~h}$ and the $\mathrm{pH}$ was adjusted to 1 with concentrated $\mathrm{HCl}$. The resulting yellow solid was collected by filtration and washed with water several times, and diethyl ether, and then dried under vacuum to give 94\% yield (1.2822 g, 1.88 mmol). ${ }^{1} \mathrm{H}$ NMR (DMSO-d $): \delta 7.86(\mathrm{~d}, 8 \mathrm{H}), 8.09$ (s, 2H), $8.17(\mathrm{~d}, 8 \mathrm{H}), 8.21(\mathrm{~s}, 4 \mathrm{H})$, $13.12(\mathrm{~s}, 4 \mathrm{H})$.

Synthesis of $1 \mathrm{~A}$ mixture of $\mathrm{Zn}\left(\mathrm{NO}_{3}\right)_{2}(29 \mathrm{mg}, 0.1 \mathrm{mmol}), \mathrm{H}_{4} \mathrm{TBAPy}(12 \mathrm{mg}, 0.02$ mmol), 6-BA (5 mg, $0.02 \mathrm{mmol}), \mathrm{DMF} / \mathrm{H}_{2} \mathrm{O}(4.5 \mathrm{~mL}, 8 / 1, \mathrm{v} / \mathrm{v})$, and the $\mathrm{pH}$ was adjusted to 3 with concentrated $\mathrm{HNO}_{3}(60 \mathrm{uL})$ were sealed in a Pyrex glass tube and heated in an oven at $120^{\circ} \mathrm{C}$ for $72 \mathrm{~h}$. After cooling to room temperature at rates of 5 ${ }^{\circ} \mathrm{C} / \mathrm{h}$, the yellow plate-like crystals were obtained by filtration and washed with DMF 3 times (4.0 mL each time, yield $60 \%$ based on $\mathrm{H}_{4}$ TBAPy), which is determined as $\left(\mathrm{Me}_{2} \mathrm{NH}_{2}\right)_{2}\left[\left(\mathrm{Zn} 8(\mathrm{TBAPy})_{3}(6 \mathrm{BA})_{4}\left(\mu_{4}-\mathrm{O}\right)\left(\mathrm{H}_{2} \mathrm{O}\right)_{4}\right](\mathrm{DMF})_{8}\left(\mathrm{H}_{2} \mathrm{O}\right)_{6}\right.$ (1). Anal. Calcd for 
$\mathrm{C}_{208} \mathrm{H}_{198} \mathrm{~N}_{30} \mathrm{O}_{43} \mathrm{Zn}_{8}: \mathrm{C}, 57.71 ; \mathrm{H}, 4.610 ; \mathrm{N}, 9.71$. Found: $\mathrm{C}, 57.47 ; \mathrm{H}, 4.465 ; \mathrm{N}, 9.68$. IR spectrum (KBr, pellets, $\mathrm{cm}^{-1}$ ): 3455.44 (vs), 2972.69 (w), 2928.54 (w), 2863.78 (w), $1627.47(\mathrm{~s}), 1559.77(\mathrm{w}), 1539.17(\mathrm{w}), 1456.75(\mathrm{w}), 1400.82(\mathrm{~m}), 1256.58(\mathrm{w})$, $1212.43(\mathrm{w}), 1177.11(\mathrm{w}), 1100.57(\mathrm{w}), 1006.38(\mathrm{w}), 791.50(\mathrm{w}), 717.91(\mathrm{w}), 647.26$ (w), $470.65(\mathrm{w})$.

Synthesis of 1-acetone About $12 \mathrm{mg}$ of 1 was immersed in $3.0 \mathrm{~mL}$ of acetone overnight, and the crystals were collected, which is determined as $\left(\mathrm{Me}_{2} \mathrm{NH}_{2}\right)_{2}\left[\left(\mathrm{Zn} 8(\mathrm{TBAPy})_{3}(6 \mathrm{BA})_{4}\left(\mu_{4}-\mathrm{O}\right)\left(\mathrm{H}_{2} \mathrm{O}\right)_{4}\right]\left(\mathrm{C}_{3} \mathrm{H}_{6} \mathrm{O}\right)_{10}\left(\mathrm{H}_{2} \mathrm{O}\right)_{5}\right.$ (1-acetone). Anal. Calcd for $\mathrm{C}_{214} \mathrm{H}_{200} \mathrm{~N}_{22} \mathrm{O}_{44} \mathrm{Zn} 8$ : C, 59.67; H, 4.680; N, 7.15. Found: C, 59.45; H, 4.310; N, 7.20. IR spectrum (KBr, pellets, $\mathrm{cm}^{-1}$ ): 3308.69 (s), 3061.66 (w), 1605.40 (s), 1544.32 (s), 1451.38 (w), 1403.97 (m), 1281.29 (w), $1223.61(\mathrm{w}), 1173.39(\mathrm{w})$, $1141.79(w), 853.68(w), 787.16(w), 720.51(w), 649.51(w), 459.04(w)$.

\section{Determination of the Crystal Structures}

Single-crystal X-ray diffraction data for $\mathbf{1}$, and 1-acetone were collected via an Oxford Cryo stream system on a XtaLAB PRO MM007-DW diffractometer system equipped with a RA-Micro7HF-MR-DW(Cu/Mo) X-ray generator and Pilatus3R-200K-A detector (Rigaku, Japan, $\mathrm{Cu} \mathrm{K \alpha}, \lambda=1.54178 \AA$ ) at 100(2) K. The numerical absorption corrections were applied using the program of ABSCOR. The structures were solved using direct methods, which yielded the positions of all non-hydrogen atoms. These were refined first isotropically and then anisotropically. All of the hydrogen atoms of the ligands were placed in calculated positions with fixed isotropic thermal parameters and included in the structure factor calculations in the final stage of full-matrix least-squares refinement. All calculations were performed using the SHELXTL system of computer programs. ${ }^{2,3}$ The unit cell volume included a large region of disordered solvent which could not be modelled as discrete atomic sites. The treatment for the guest molecules in the cavities of all crystals involves the use of the SQUEEZE program of PLATON. ${ }^{4}$ Crystal data and structure refinement parameters are summarized in Tables S1-S3. 
Table S1 Crystal data and structure refinements for $\mathbf{1}$ and $\mathbf{1 - a c e t o n e}$

\begin{tabular}{|c|c|c|}
\hline & 1 & 1-acetone \\
\hline Formula & $\mathrm{C}_{208} \mathrm{H}_{198} \mathrm{~N}_{30} \mathrm{O}_{43} \mathrm{Zn}_{8}$ & $\mathrm{C}_{214} \mathrm{H}_{200} \mathrm{~N}_{22} \mathrm{O}_{44} \mathrm{Zn} 8$ \\
\hline Mr. & 4329.09 & 4307.11 \\
\hline Crystal system & Monoclinic & Monoclinic \\
\hline Space group & $\mathrm{P} 2 / \mathrm{c}$ & $\mathrm{P} 2 / \mathrm{n}$ \\
\hline Temp (K) & $100.00(10)$ & $99.99(14)$ \\
\hline $\mathrm{a}(\AA)$ & $25.6234(6)$ & $25.5968(8)$ \\
\hline $\mathrm{b}(\AA)$ & $16.36975(19)$ & $16.5121(2)$ \\
\hline $\mathrm{c}(\AA)$ & $26.8850(7)$ & $26.7970(7)$ \\
\hline$\alpha\left(^{\circ}\right)$ & 90 & 90 \\
\hline$\beta\left(^{\circ}\right)$ & $118.418(3)$ & $117.805(4)$ \\
\hline$\gamma\left({ }^{\circ}\right)$ & 90 & 90 \\
\hline $\mathrm{V}\left(\AA^{3}\right)$ & $9918.0(4)$ & $10018.2(5)$ \\
\hline $\mathrm{Z}$ & 2 & 2 \\
\hline$D_{c}\left(g \cdot \mathrm{cm}^{-3}\right)$ & 1.187 & 1.213 \\
\hline no. of reflns & 42047 & 57567 \\
\hline no. of unique & 14410 & 18630 \\
\hline data collected & 3.284 to 62.998 & 3.268 to 70.907 \\
\hline unique refl.( $\left.\mathrm{R}_{\text {int }}\right)$ & 0.0323 & 0.0420 \\
\hline GOF on $\mathrm{F}^{2}$ & 1.047 & 1.063 \\
\hline $\mathrm{R}_{1}[\mathrm{I} \geq 2 \sigma(\mathrm{I})]^{\mathrm{a}}$ & 0.0981 & 0.0975 \\
\hline $\mathrm{wR}_{2}[\mathrm{I} \geq 2 \sigma(\mathrm{I})]^{\mathrm{b}}$ & 0.2924 & 0.3120 \\
\hline $\mathrm{R}_{1}$ [all data $]$ & 0.1092 & 0.1190 \\
\hline$w_{2}$ [all data] & 0.3051 & 0.3437 \\
\hline
\end{tabular}

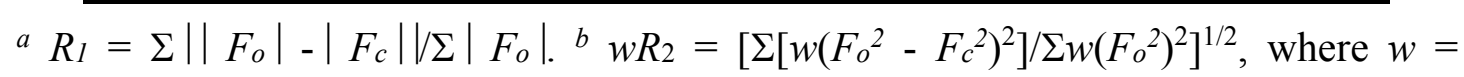
$1 /\left[\sigma^{2}\left(F_{o}\right)^{2}+(a P)^{2}+b P\right]$ and $P=\left(F_{o}^{2}+2 F_{\mathrm{c}}{ }^{2}\right) / 3$. 
Table S2 Selected bond lengths $(\AA)$ and angles $\left(^{\circ}\right)$ for $\mathbf{1}$

\begin{tabular}{|c|c|c|c|}
\hline \multicolumn{4}{|c|}{1} \\
\hline $\mathrm{Zn}(1)-\mathrm{O}(1)$ & $1.975(2)$ & $\mathrm{Zn}(1)-\mathrm{N}(6)$ & $2.018(5)$ \\
\hline $\mathrm{Zn}(1)-\mathrm{N}(1) \# 1$ & $2.016(4)$ & $\mathrm{Zn}(1)-\mathrm{O}(3) \# 2$ & $1.953(4)$ \\
\hline $\mathrm{Zn}(2)-\mathrm{O}(1)$ & $1.975(2)$ & $\mathrm{Zn}(2)-\mathrm{O}(2)$ & $1.963(4)$ \\
\hline $\mathrm{Zn}(2)-\mathrm{N}(2)$ & $2.012(4)$ & $\mathrm{Zn}(2)-\mathrm{N}(4) \# 1$ & $2.020(5)$ \\
\hline $\mathrm{Zn}(3)-\mathrm{N}(3)$ & $1.996(5)$ & $\mathrm{Zn}(3)-\mathrm{O}(6)$ & $1.989(5)$ \\
\hline $\mathrm{Zn}(3)-\mathrm{O}(9)$ & $2.006(6)$ & $\mathrm{Zn}(3)-\mathrm{O}(10) \# 3$ & $2.017(6)$ \\
\hline $\mathrm{Zn}(4)-\mathrm{N}(5)$ & $1.988(5)$ & $\mathrm{Zn}(4)-\mathrm{O}(7)$ & $1.951(6)$ \\
\hline $\mathrm{Zn}(4)-\mathrm{O}(8) \# 4$ & $1.962(6)$ & $\mathrm{Zn}(4)-\mathrm{O}(11)$ & $2.008(9)$ \\
\hline $\mathrm{O}(1)-\mathrm{Zn}(1)-\mathrm{N}(1) \# 1$ & $100.16(16)$ & $\mathrm{O}(1)-\mathrm{Zn}(1)-\mathrm{N}(6)$ & $99.93(17)$ \\
\hline $\mathrm{N}(1) \# 1-\mathrm{Zn}(1)-\mathrm{N}(6)$ & $118.2(2)$ & $\mathrm{O}(3) \# 2-\mathrm{Zn}(1)-\mathrm{O}(1)$ & $117.93(16)$ \\
\hline $\mathrm{O}(3) \# 2-\mathrm{Zn}(1)-\mathrm{N}(1) \# 1$ & $113.27(18)$ & $\mathrm{O}(3) \# 2-\mathrm{Zn}(1)-\mathrm{N}(6)$ & $107.0(2)$ \\
\hline $\mathrm{O}(1)-\mathrm{Zn}(2)-\mathrm{N}(2)$ & $99.23(16)$ & $\mathrm{O}(1)-\mathrm{Zn}(2)-\mathrm{N}(4) \# 1$ & $101.15(15)$ \\
\hline $\mathrm{O}(2)-\mathrm{Zn}(2)-\mathrm{O}(1)$ & $117.73(15)$ & $\mathrm{O}(2)-\mathrm{Zn}(2)-\mathrm{N}(2)$ & $113.97(18)$ \\
\hline $\mathrm{O}(2)-\mathrm{Zn}(2)-\mathrm{N}(4) \# 1$ & $106.80(19)$ & $\mathrm{N}(2)-\mathrm{Zn}(2)-\mathrm{N}(4) \# 1$ & $117.6(2)$ \\
\hline $\mathrm{N}(3)-\mathrm{Zn}(3)-\mathrm{O}(9)$ & $99.1(3)$ & $\mathrm{N}(3)-\mathrm{Zn}(3)-\mathrm{O}(10) \# 3$ & 107.1(3) \\
\hline $\mathrm{N}(3)-\mathrm{Zn}(3)-\mathrm{O}(12) \# 3$ & $98.4(3)$ & $\mathrm{O}(6)-\mathrm{Zn}(3)-\mathrm{N}(3)$ & $102.5(2)$ \\
\hline $\mathrm{O}(6)-\mathrm{Zn}(3)-\mathrm{O}(9)$ & $96.4(3)$ & $\mathrm{O}(6)-\mathrm{Zn}(3)-\mathrm{O}(10) \# 3$ & $144.9(3)$ \\
\hline $\mathrm{N}(5)-\mathrm{Zn}(4)-\mathrm{O}(11)$ & $99.9(3)$ & $\mathrm{O}(7)-\mathrm{Zn}(4)-\mathrm{O}(11)$ & $97.6(3)$ \\
\hline $\mathrm{O}(7)-\mathrm{Zn}(4)-\mathrm{N}(5)$ & $109.8(3)$ & $\mathrm{O}(8) \# 4-\mathrm{Zn}(4)-\mathrm{N}(5)$ & $106.0(2)$ \\
\hline $\mathrm{O}(7)-\mathrm{Zn}(4)-\mathrm{O}(8) \# 4$ & $130.5(3)$ & $\mathrm{O}(8) \# 4-\mathrm{Zn}(4)-\mathrm{O}(11)$ & $108.9(4)$ \\
\hline
\end{tabular}

Symmetry transformations used to generate equivalent atoms: $\# 1 \mathrm{x}-1,-\mathrm{y}+1, \mathrm{z}-1 / 2$; $\# 2-x, y-1,-z+1 / 2 ; \# 3 x, y+1, z ; \# 4 x, y-1, z$ 
Table S3 Selected bond lengths $(\AA)$ and angles $\left(^{\circ}\right)$ for $\mathbf{1}$-acetone

\begin{tabular}{|c|c|c|c|}
\hline \multicolumn{4}{|c|}{ 1-acetone } \\
\hline $\mathrm{Zn}(1)-\mathrm{O}(1)$ & $1.978(3)$ & $\mathrm{Zn}(1)-\mathrm{N}(1)$ & $2.016(4)$ \\
\hline $\mathrm{Zn}(1)-\mathrm{O}(3) \# 1$ & $1.967(4)$ & $\mathrm{Zn}(1)-\mathrm{N}(5)$ & $2.023(5)$ \\
\hline $\mathrm{Zn}(2)-\mathrm{O}(1)$ & $1.973(3)$ & $\mathrm{Zn}(2)-\mathrm{N}(2)$ & $2.000(4)$ \\
\hline $\mathrm{Zn}(2)-\mathrm{O}(2)$ & $1.964(4)$ & $\mathrm{Zn}(2)-\mathrm{N}(4)$ & $2.043(5)$ \\
\hline $\mathrm{Zn}(3)-\mathrm{N}(3)$ & $2.016(4)$ & $\mathrm{Zn}(3)-\mathrm{O}(8)$ & $1.997(6)$ \\
\hline $\mathrm{Zn}(3)-\mathrm{O}(6) \# 2$ & $1.993(5)$ & $\mathrm{Zn}(3)-\mathrm{O}(9) \# 3$ & $2.025(5)$ \\
\hline $\mathrm{Zn}(4)-\mathrm{N}(7)$ & $1.992(5)$ & $\mathrm{Zn}(4)-\mathrm{O}(11)$ & $1.954(5)$ \\
\hline $\mathrm{Zn}(4)-\mathrm{O}(7) \# 4$ & $1.995(6)$ & $\mathrm{Zn}(4)-\mathrm{O}(12)$ & $2.013(7)$ \\
\hline $\mathrm{O}(1)-\mathrm{Zn}(1)-\mathrm{N}(1)$ & $99.82(17)$ & $\mathrm{O}(1)-\mathrm{Zn}(1)-\mathrm{N}(5)$ & $100.62(16)$ \\
\hline $\mathrm{N}(1)-\mathrm{Zn}(1)-\mathrm{N}(5)$ & $117.2(2)$ & $\mathrm{O}(3) \# 1-\mathrm{Zn}(1)-\mathrm{O}(1)$ & $117.26(17)$ \\
\hline $\mathrm{O}(3) \# 1-\mathrm{Zn}(1)-\mathrm{N}(1)$ & $113.98(17)$ & $\mathrm{O}(3) \# 1-\mathrm{Zn}(1)-\mathrm{N}(5)$ & $107.5(2)$ \\
\hline $\mathrm{O}(1)-\mathrm{Zn}(2)-\mathrm{N}(2)$ & $99.04(17)$ & $\mathrm{O}(2)-\mathrm{Zn}(2)-\mathrm{N}(2)$ & $115.42(18)$ \\
\hline $\mathrm{O}(1)-\mathrm{Zn}(2)-\mathrm{N}(4)$ & $101.94(14)$ & $\mathrm{O}(2)-\mathrm{Zn}(2)-\mathrm{N}(4)$ & $107.34(19)$ \\
\hline $\mathrm{O}(2)-\mathrm{Zn}(2)-\mathrm{O}(1)$ & $116.19(17)$ & $\mathrm{N}(2)-\mathrm{Zn}(2)-\mathrm{N}(4)$ & $116.2(2)$ \\
\hline $\mathrm{N}(3)-\mathrm{Zn}(3)-\mathrm{O}(9) \# 3$ & $108.1(2)$ & $\mathrm{O}(6) \# 2-\mathrm{Zn}(3)-\mathrm{N}(3)$ & $100.5(2)$ \\
\hline $\mathrm{N}(3)-\mathrm{Zn}(3)-\mathrm{O}(10) \# 3$ & $97.2(2)$ & $\mathrm{O}(6) \# 2-\mathrm{Zn}(3)-\mathrm{O}(8)$ & $96.0(3)$ \\
\hline $\mathrm{O}(8)-\mathrm{Zn}(3)-\mathrm{N}(3)$ & $99.7(2)$ & $\mathrm{O}(6) \# 2-\mathrm{Zn}(3)-\mathrm{O}(10) \# 3$ & $102.0(2)$ \\
\hline $\mathrm{N}(7)-\mathrm{Zn}(4)-\mathrm{O}(7) \# 4$ & $105.1(2)$ & $\mathrm{O}(11)-\mathrm{Zn}(4)-\mathrm{N}(7)$ & $109.2(2)$ \\
\hline $\mathrm{N}(7)-\mathrm{Zn}(4)-\mathrm{O}(12)$ & $102.3(2)$ & $\mathrm{O}(11)-\mathrm{Zn}(4)-\mathrm{O}(12)$ & $97.9(3)$ \\
\hline $\mathrm{O}(7) \# 4-\mathrm{Zn}(4)-\mathrm{O}(12)$ & $108.2(3)$ & $\mathrm{O}(11)-\mathrm{Zn}(4)-\mathrm{O}(7) \# 4$ & $130.7(3)$ \\
\hline
\end{tabular}

Symmetry transformations used to generate equivalent atoms: $\# 1-x+3 / 2, y+1,-z+3 / 2$; $\# 2 \mathrm{x}-1 / 2,-\mathrm{y}, \mathrm{z}+1 / 2 ; \# 3 \mathrm{x}-1 / 2,-\mathrm{y}+1, \mathrm{z}+1 / 2 ; \# 4 \mathrm{x}, \mathrm{y}+1, \mathrm{z}$

Topological Analysis For comprehending the underlying topology information of $\mathbf{1}$, the simplification net can be achieved by denoting the analogous $\mathrm{Zn}_{4} \mathrm{O}$ SBU as an eight-connected (8-c) node, the mononuclear SBU as a (3-c) and TBAPy ligand as (4-c) node, respectively, giving a $(3,3,4,4,8-c)$ net with the point symbol of 
$\left.\left\{4 \cdot 6^{2}\right\} 44^{2} \cdot 6^{2} \cdot 8^{2}\right\}\left\{4^{3} \cdot 6^{3}\right\}_{2}\left\{4^{4} \cdot 6^{18} \cdot 8^{6}\right\}$. A rigorous topological identification for the net of 1 can be computed by the program Systre ${ }^{5}$ and TOPOS 6 .

\section{Luminescence Quenching Measurements}

1 was chosen for the luminescence studies because of the excellent luminescent properties of Pyrene-based ligand TBAPy. $0.1 \mathrm{mg}$ of 1 was dispersed in a series of organic solvents $(2 \mathrm{~mL})$ such as Chloroform, DMF, DMA, methanol, ethanol, 1-propanol, isopropanol, acetonitrile, dichloromethane, and acetone, respectively. Luminescence spectra $\left(\lambda_{\mathrm{ex}}=280 \mathrm{~nm}\right)$ were recorded during the parallel determination. Acetone was chosen for the further study of anti-interference because of its excellent quenching efficiency. In order to correlate the acetone concentration and magnitude of quenching, the luminescence emissions $\mathbf{1}$ were recorded as the concentration of acetone increasing from 0 to $47.67 \mathrm{mmol} / \mathrm{L}$, then the maximum intensities were used to plot against the acetone concentrations to generate a Stern-Volmer curve.

The recyclability of $\mathbf{1}$ was evaluated with the following procedure: for each cycle, $0.3 \mathrm{mg}$ of 1 was dispersed in $3 \mathrm{ml}$ of chloroform and it was recorded for its emission intensity, then $20 \mu \mathrm{L}$ of acetone was added to quench the emission. After that, the supernatant liquid was removed by centrifuge and the solid was washed thoroughly with DMF for next use.

Table S4 Selected luminescent materials for acetone sensing

\begin{tabular}{lllll}
\hline No. & Luminescent materials & solution & Detection limit & ref \\
\hline 1 & {$\left[\mathrm{Cu}(\mathrm{tpp}) \mathrm{H}_{2} \mathrm{O}\right]_{2 \mathrm{n}}$} & Aqueous solutions & $0.0842 \mathrm{vol} \%$ & 7 \\
2 & {$[\mathrm{Cd}(\mathrm{Tipb})(\mathrm{mta})](\mathrm{DMF})_{\mathrm{x}}\left(\mathrm{H}_{2} \mathrm{O}\right)_{\mathrm{y}}$} & acetonitrile & $0.075 \mathrm{vol} \%$ & 8 \\
3 & {$\left[\mathrm{Cd}_{2}(\mathrm{tib})_{2}(\mathrm{bda})_{2}\right] \cdot(\text { solvent })_{\mathrm{n}}$} & Aqueous solutions & $55 \mathrm{ppm}$ & 9 \\
4 & $\mathrm{Zn-PDC} / \mathrm{Tb}^{3+}$ & Aqueous solutions & $55 \mathrm{ppm}$ & 10 \\
5 & Eu-BPDA & methanol & $0.028 \mathrm{vol} \%$ & 11 \\
& & & EC50 & \\
6 & $\mathbf{1}$ & $\mathrm{CHCl}_{3}$ & $1.85 \mathrm{ppm}$ & This work \\
\hline
\end{tabular}


<smiles>O=C(O)c1ccc(-c2cc(-c3ccc(C(=O)O)cc3)c3ccc4c(-c5ccc(C(=O)O)cc5)cc(-c5ccc(C(=O)O)cc5)c5ccc2c3c54)cc1</smiles>

1,3,6,8-tetrakis (p-benzoic acid)pyrene $\mathrm{H}_{4}$ TBAPy<smiles>c1ccc(CNc2ncnc3[nH]cnc23)cc1</smiles>

6-Benzylaminopurine 6-BA

Scheme S1 The $\mathrm{H}_{4} \mathrm{TBAPy}$ and 6-BA ligands used for the construction of $\mathbf{1}$.

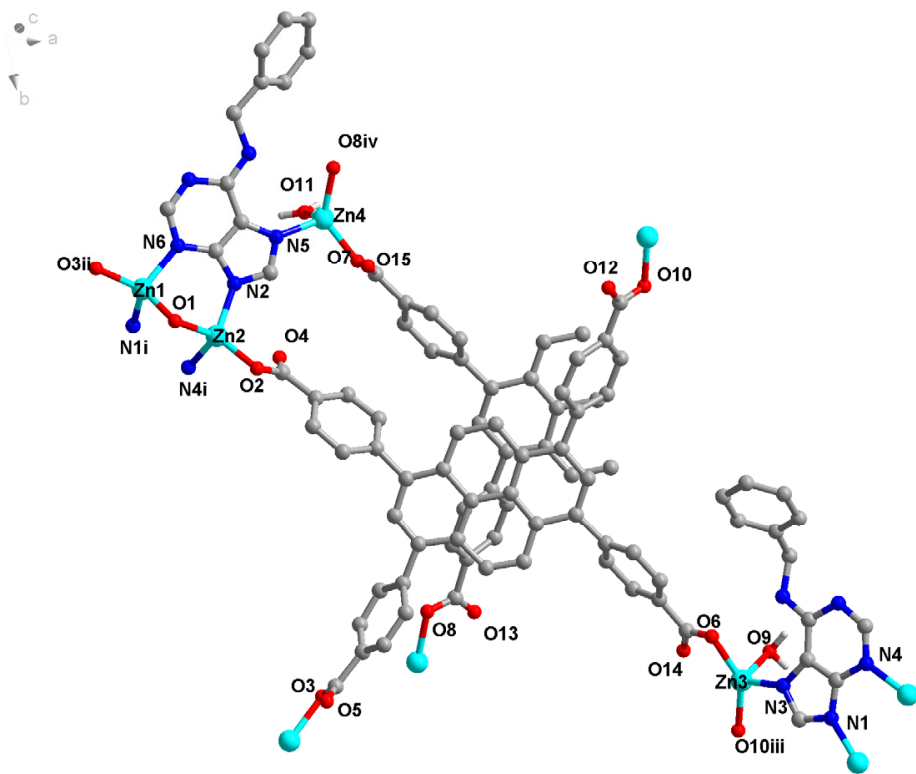

Figure S1. The coordination environments of $\mathrm{Zn}(\mathrm{II}), \mathrm{TBAPy}{ }^{4-}$ and 6-BA anion in $\mathbf{1}$ (symmetry operations: i: $-1+\mathrm{x}, 1-\mathrm{y},-1 / 2+\mathrm{z}$; ii: $-\mathrm{x},-1+\mathrm{y}, 1 / 2-\mathrm{z}$; iii: $\mathrm{x}, 1+\mathrm{y}, \mathrm{z}$ and iv: $\mathrm{x},-1+\mathrm{y}, \mathrm{z})$. 
a

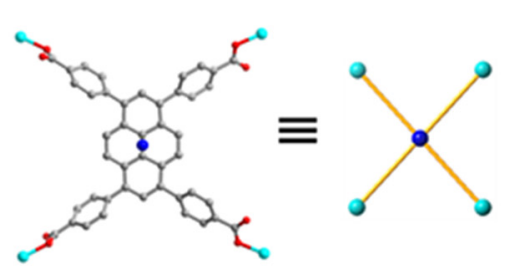

c

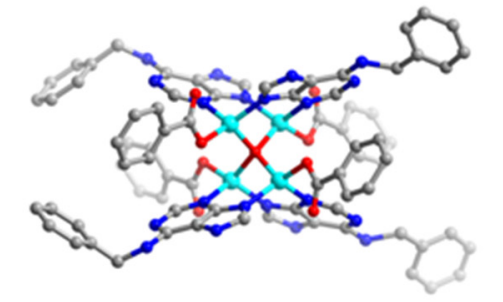

d

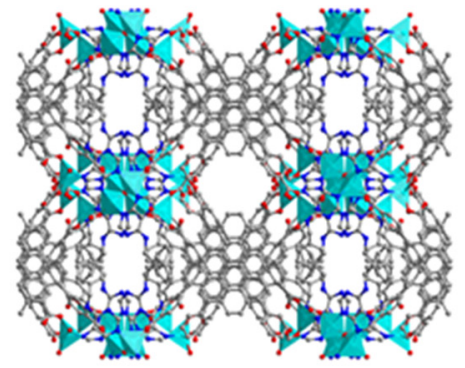

b

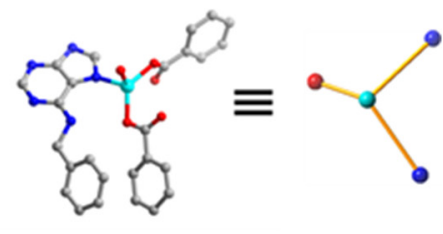

e

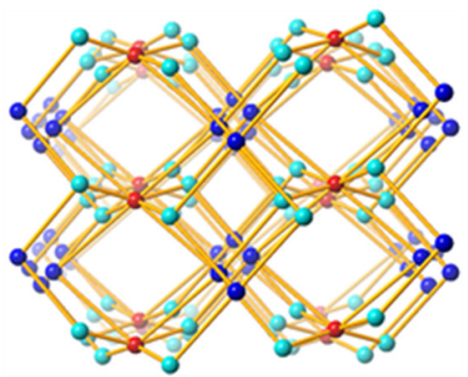

Figure S2. The secondary building unit and topological structure of $\mathbf{1}$.

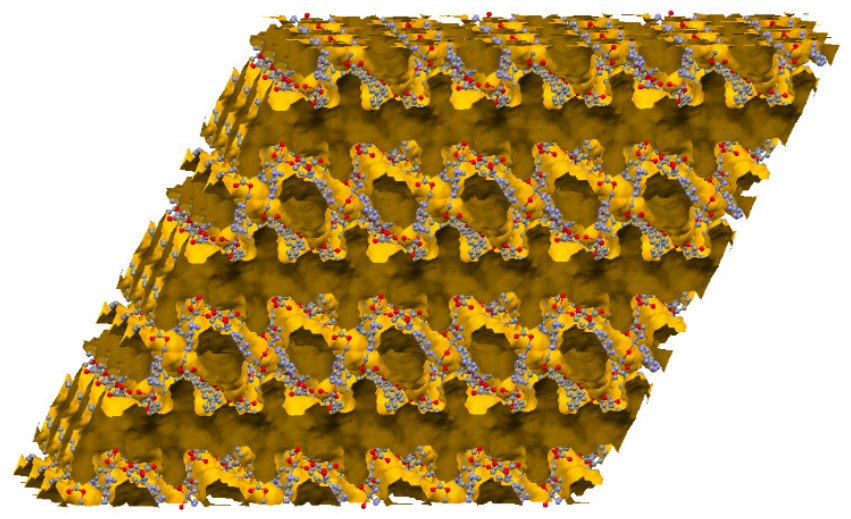

Figure S3. side-view of the 1D channel of the framework structures. 


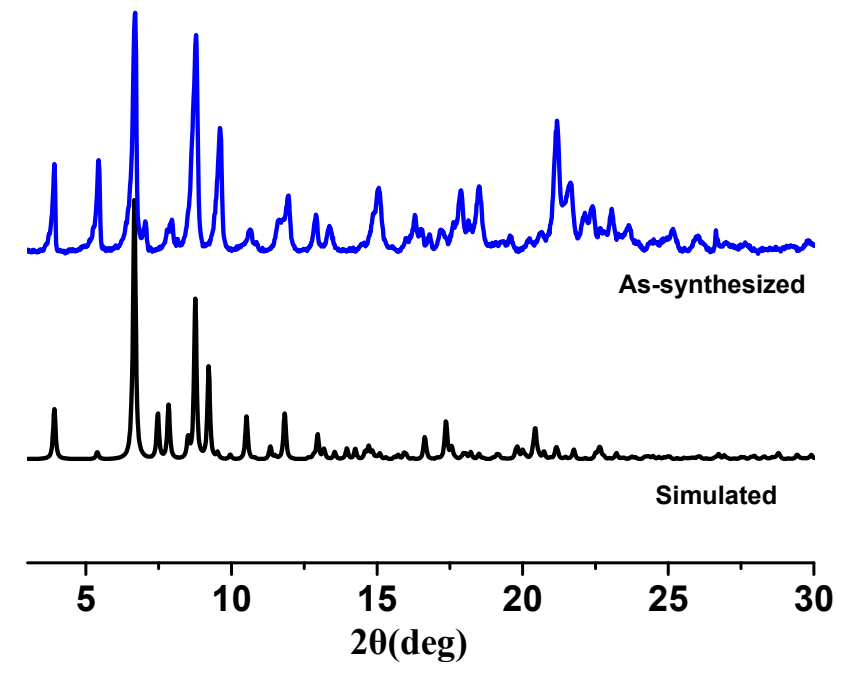

Figure S4. The PXRD patterns of 1.

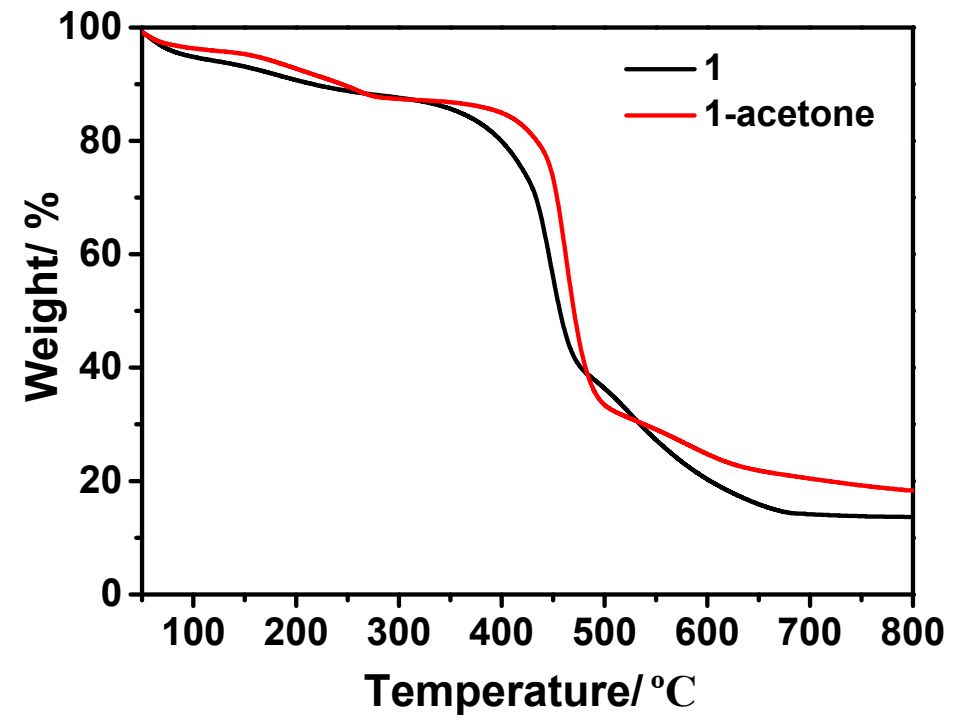

Figure S5. Thermogravimetric analysis of $\mathbf{1}$ and $\mathbf{1 - a c e t o n e .}$ 


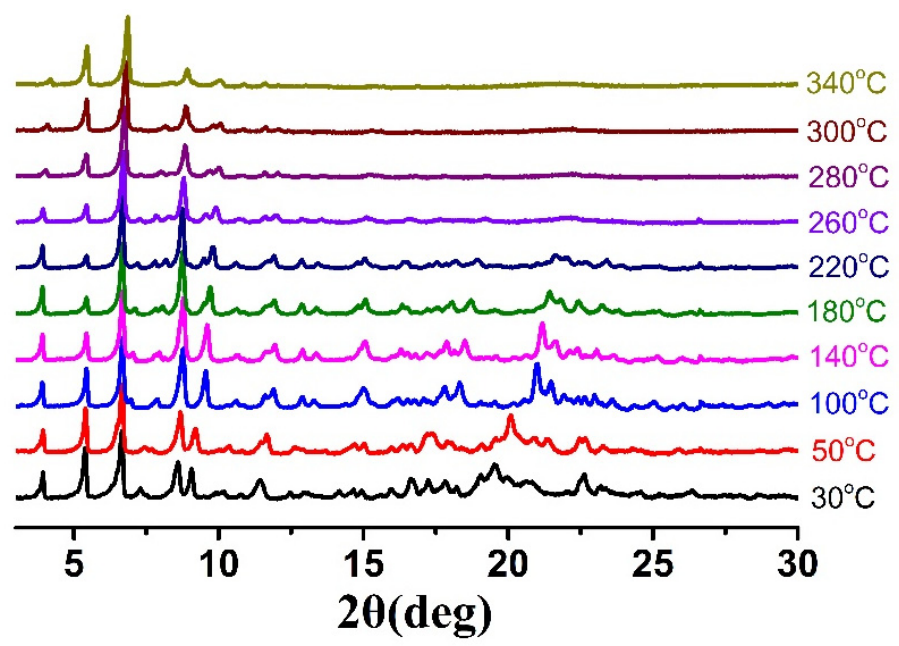

Figure S6. The variable temperature PXRD patterns for as-synthesized $\mathbf{1}$ in $\mathrm{N}_{2}$.

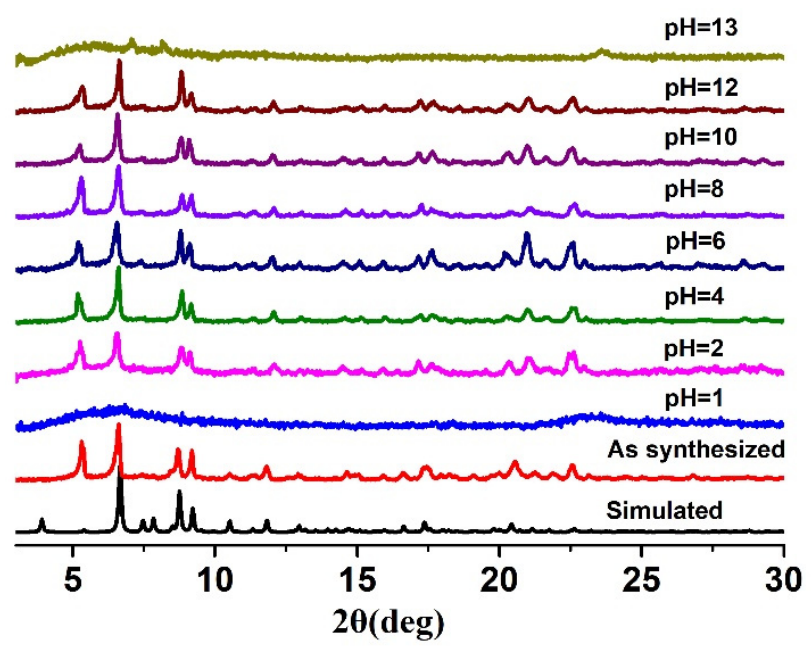

Figure S7. PXRD patterns of 1 after treated with aqueous solutions at various $\mathrm{pH}$ values from 1 to 13. 


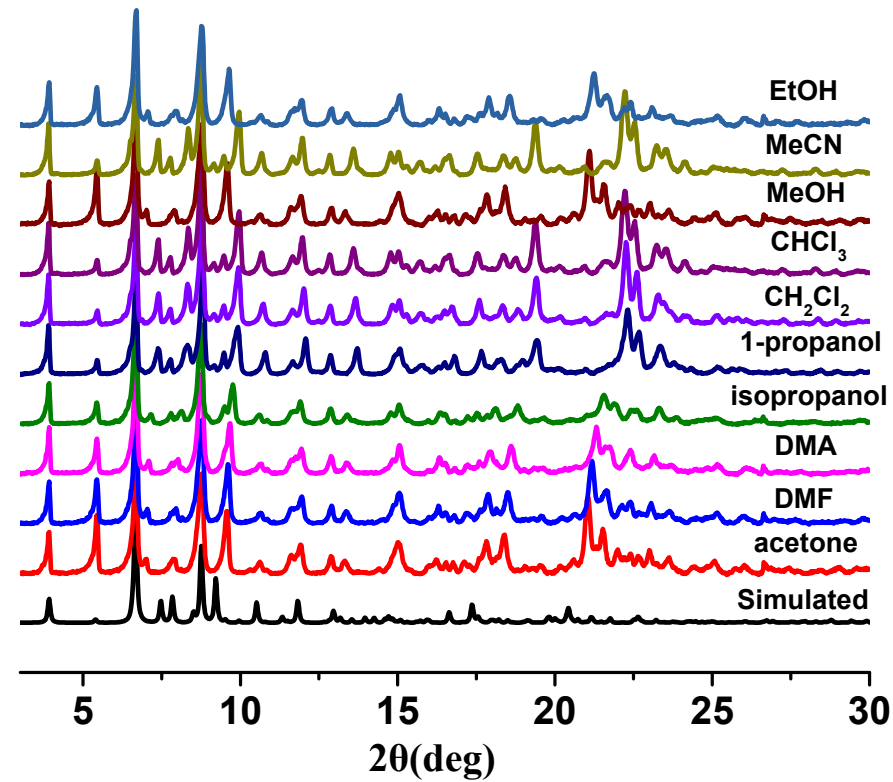

Figure S8. PXRD patterns of $\mathbf{1}$ soaked in different organic solvents.

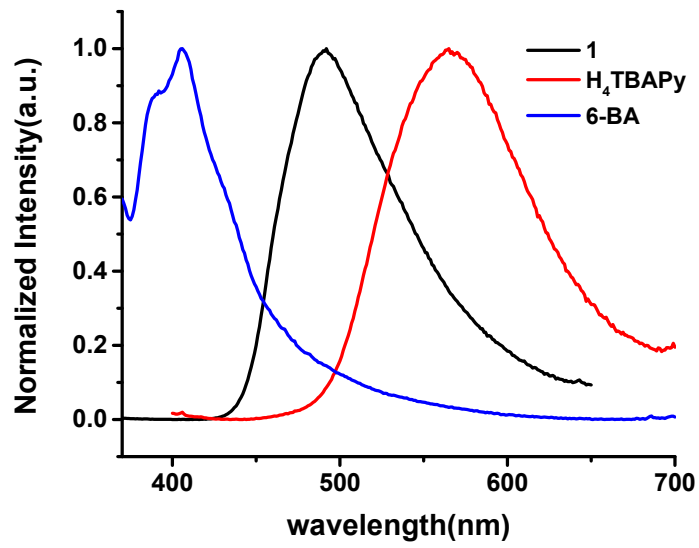

Figure S9. Solid-state emission spectra of $\mathrm{H}_{4} \mathrm{TBAPy}$ (red), 6-BA (blue) and $\mathbf{1}$ (black). 


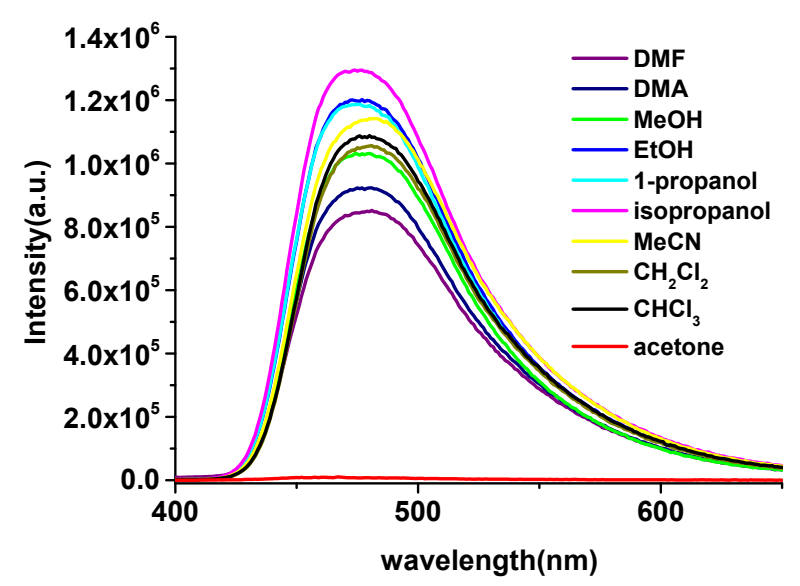

Figure S10. The luminescence spectra of 1 when dispersed into ten kinds of organic solvents including Chloroform, DMF, DMA, methanol, ethanol, 1-propanol, isopropanol, acetonitrile, dichloromethane, acetone. The excitation wavelength is $280 \mathrm{~nm}$.

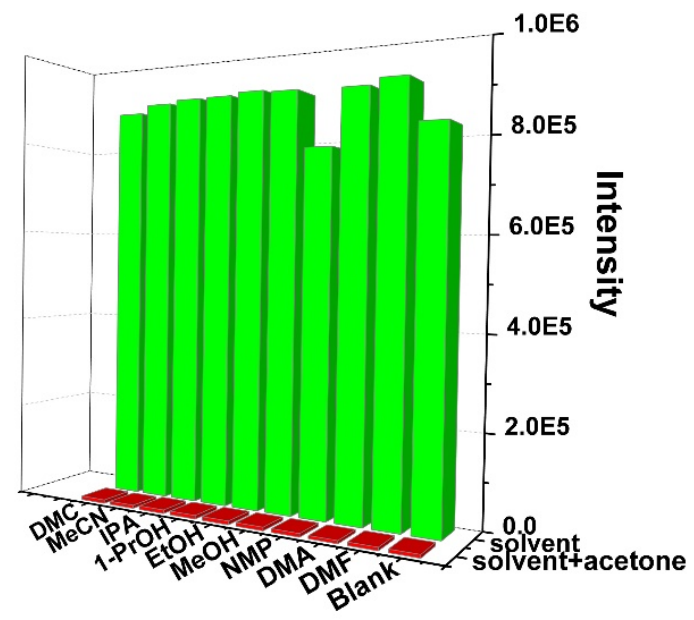

Figure S11. Luminescence responses of 1 toward acetone in the presence of other organic solvents. 


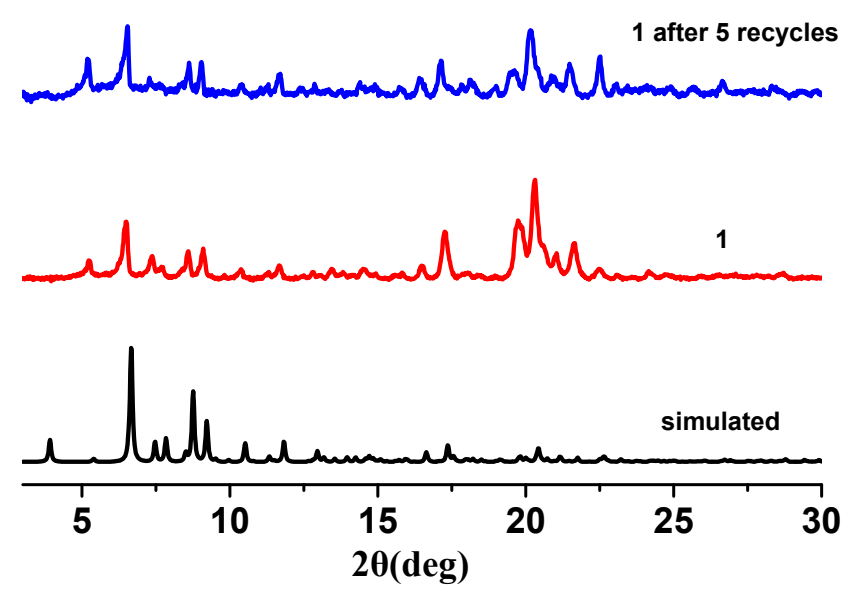

Figure S12. PXRD patterns of 1 after 5 recycles of detecting acetone.
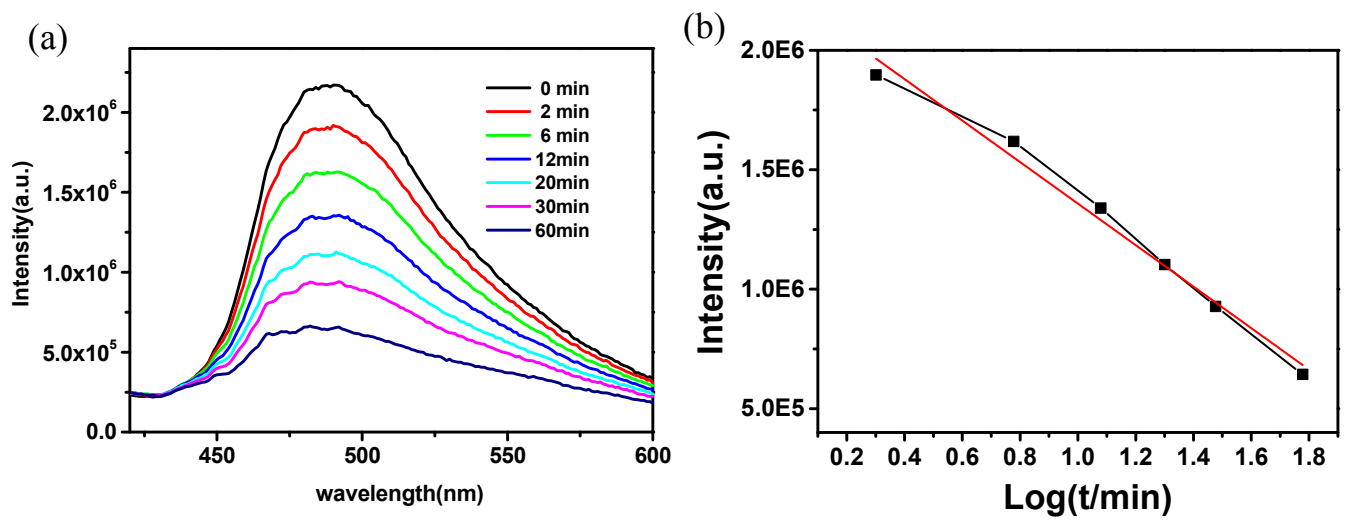

Figure S13. (a) Real-time monitoring of the solid-state emission spectra of the thin film sample of 1 in response to acetone vapour. (b) The linear relationship between emission intensity and $\log (\mathrm{t} / \mathrm{min})$ 


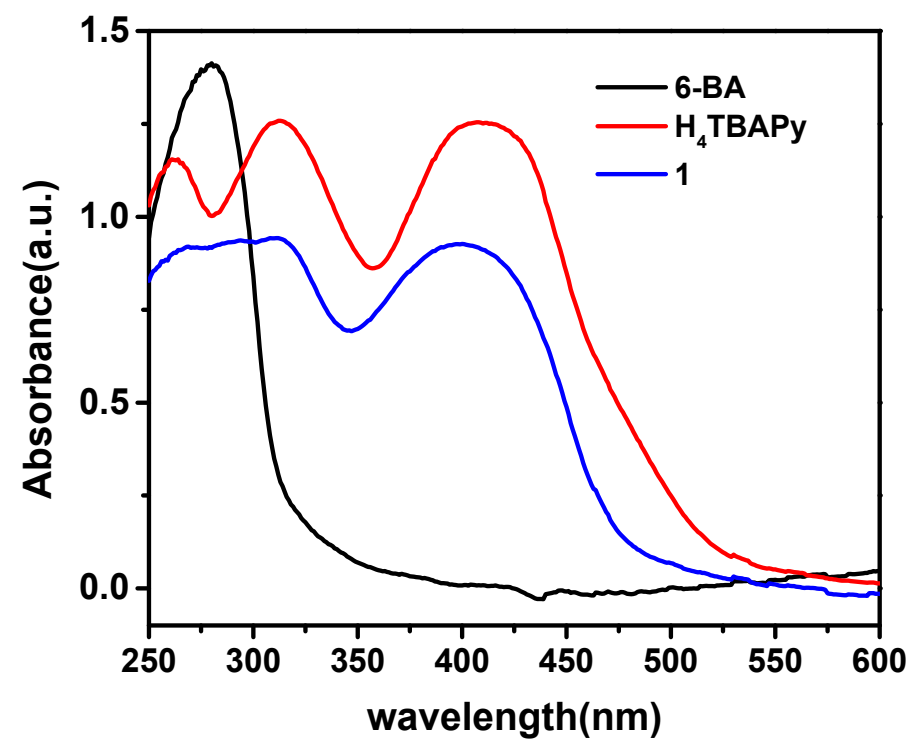

Figure S14. UV-Vis spectra of 1 (blue), H4TBAPy (red) and 6-BA (black) in the solid state.

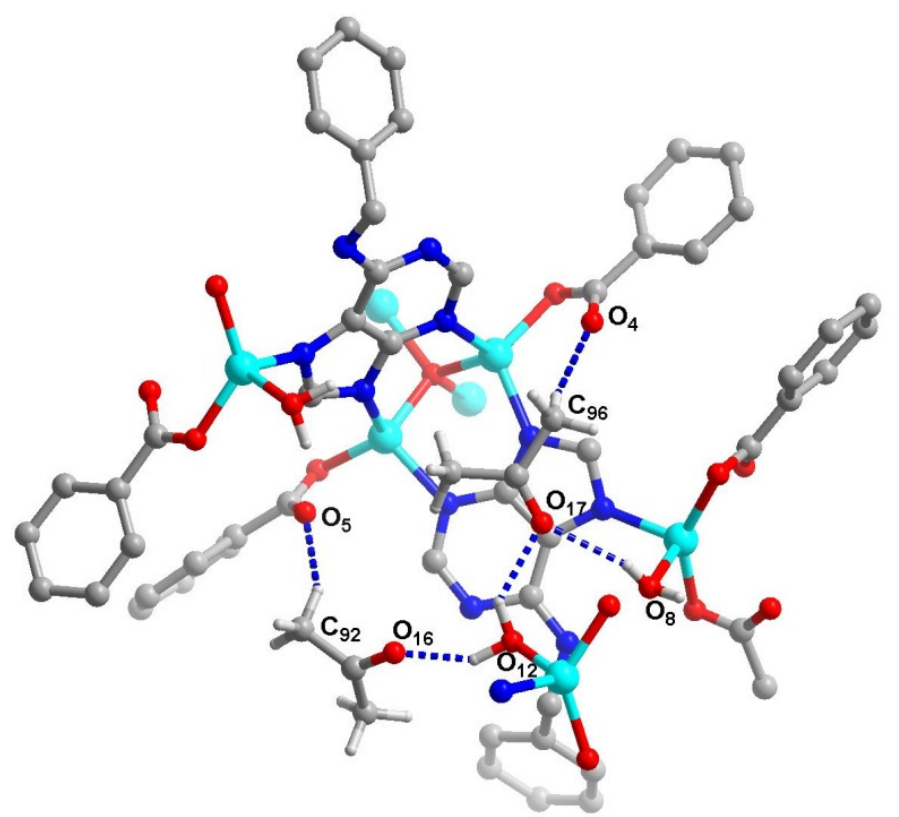

Figure S15. The hydrogen bonds between acetone and framework. The donor-acceptor distances

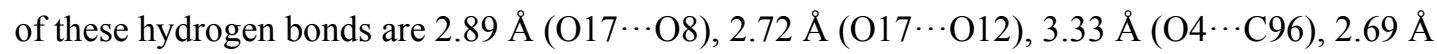

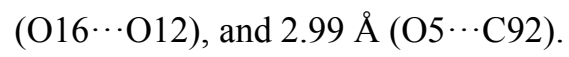




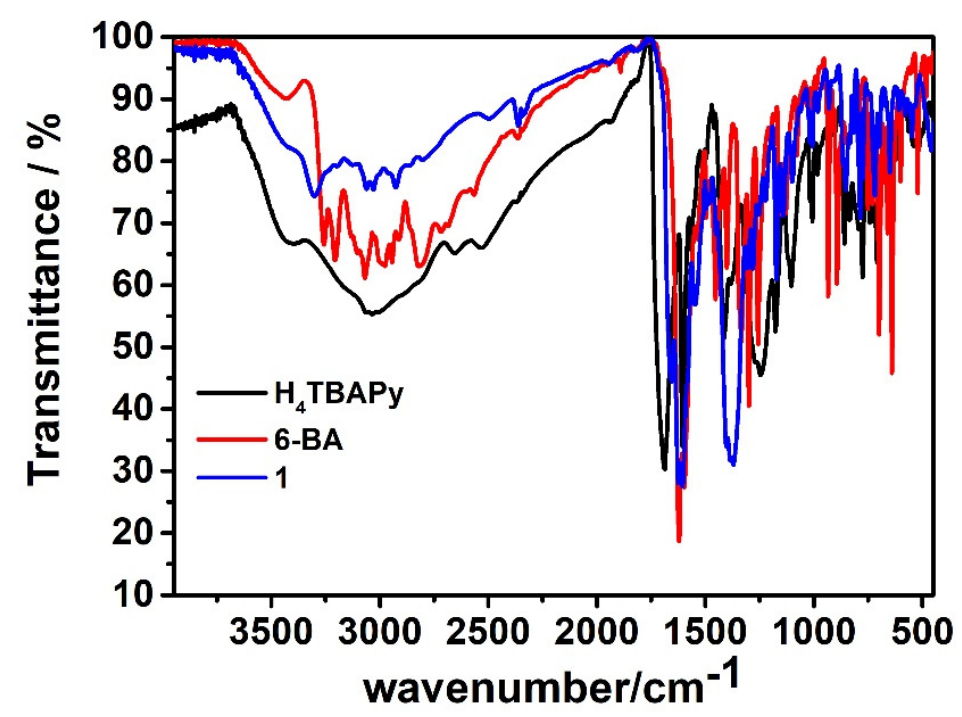

Figure S16. Selected FT-IR spectra of $\mathrm{H}_{4}$ TBAPy (black), 6-BA (red) and compound 1 (blue).

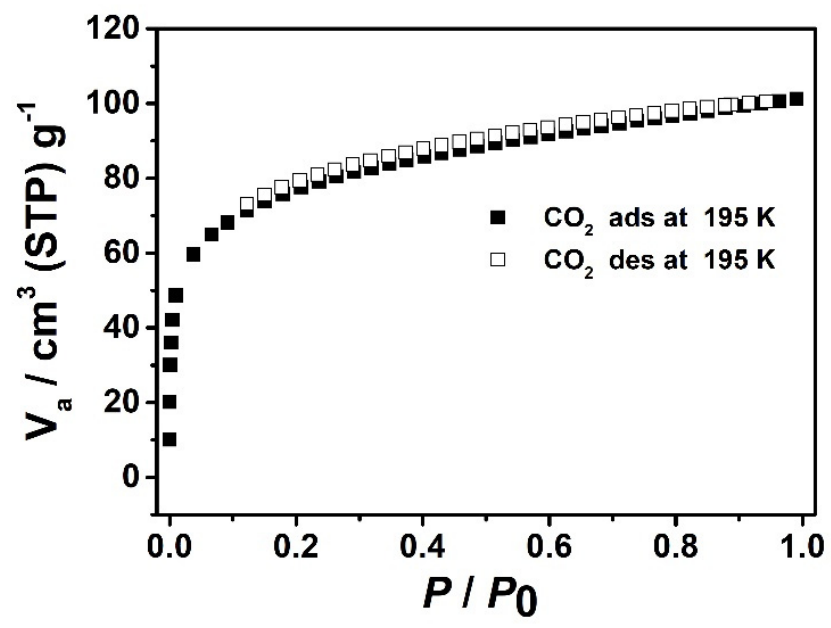

Figure S17. $\mathrm{CO}_{2}$ adsorption and desorption isotherm at $195 \mathrm{~K}$ for $\mathbf{1}$.

(a)

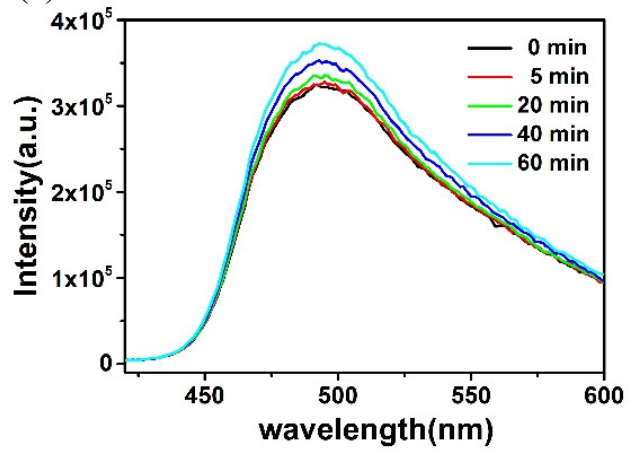

(b)

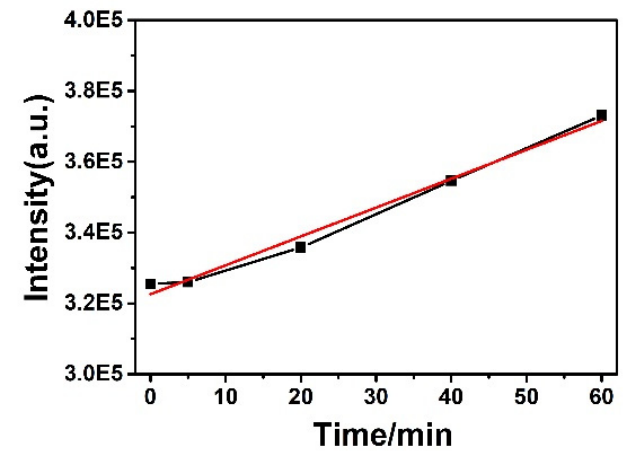


Figure S18. (a) Time-dependent monitoring of the solid-state emission spectra of the thin film sample of 1-acetone. (b) The linear relationship between emission intensity and time.

\section{References}

1.Stylianou, K. C.; Samantha, R.; Chong, S. Y.; Bacsa, J.; Jones, J. T. A.; Khimyak, Y. Z., Bradshaw, D.; Rosseinsky, M. J. A Guest-Responsive Fluorescent 3D Microporous Metal-Organic Framework Derived from a Long-Lifetime Pyrene Core. J. Am. Chem. Soc. 2010, 132, 4119-4130.

2. Hübschle, C. B.; Sheldrick, G. M.; Dittrich, B. Shelxle: A qt graphical user interface for shelxl. J. Appl. Crystallogr. 2011, 44, 1281-1284.

3. Sheldrick, G. M. A short history of shelx. Acta. Crystallogr. A. 2008, 64, 112-122.

4. Spek, A. L. Single-crystal structure validation with the program PLATON. J. Appl. Crystallogr. 2003, 36, 7-13.

5. Delgado-Friedrichs, O.; O'Keeffe, M. Identification of and symmetry computation for crystal nets Acta Crystallogr. A 2003, 59, 351-360.

6. Blatov, V. A.; Shevchenko, A. P.; Proserpio, D. M. Applied Topological Analysis of Crystal Structures with the Program Package ToposPro Cryst. Growth Des. 2014, 14, 3576-3586.

7. Song, Y.; Fan, R. Q.; Du, X.; Xing, K.; Dong, Y. W.; Wang, P.; Yang, Y. L. Dual functional fluorescent sensor for selectively detecting acetone and $\mathrm{Fe}^{3+}$ based on $\left\{\mathrm{Cu}_{2} \mathrm{~N}_{4}\right\}$ substructure bridged $\mathrm{Cu}(\mathrm{I})$ coordination polymer. RSC Adv. 2016, 6, 110182-110189.

8. Li, Y.; Song, H.; Chen, Q.; Liu, K.; Zhao, F. Y.; Ruan, W. J.; Chang, Z. Two coordination polymers with enhanced ligand-centered luminescence and assembly imparted sensing ability for acetone. J. Mater. Chem. A 2014, 2, 9469-9473.

9. Liu, X. J.; Zhang, Y. H.; Chang, Z.; Li, A. L.; Tian, D.; Yao, Z. Q.; Jia, Y. Y.; Bu, X. H. A Water-Stable Metal-Organic Framework with a Double-Helical Structure for Fluorescent Sensing. Inorg. Chem. 2016, 55, 7326-7328.

10. Pan, H.; Wang, S. F.; Dao, X. Y.; Ni, Y. H. Fluorescent Zn-PDC/Tb ${ }^{3+}$ Coordination Polymer Nanostructure: A Candidate for Highly Selective Detections of Cefixime Antibiotic and Acetone in Aqueous System. Inorg. Chem. 2018, 57, 1417-1425. 
11. Wang, J.; Wang, J. R.; Li, Y.; Jiang, M.; Zhang, L. W.; Wu, P. Y. A europium(III)-based metal-organic framework as a naked-eye and fast response luminescence sensor for acetone and ferric iron. New J. Chem. 2016, 40, 8600-8606. 